\title{
The effectiveness of hydrotherapy in patients with chronic low back pain
}

\author{
DOI: https://doi.org/10.5114/pq.2020.95772
}

\author{
Anna Christakou', Foteini Boulnta ${ }^{2}$ \\ ${ }^{1}$ Department of Physiotherapy, University of West Attica, Athens, Greece; Evangelismos Athens General Hospital, \\ Athens, Greece \\ ${ }^{2}$ Department of Physiotherapy, University of West Attica, Athens, Greece
}

\begin{abstract}
Introduction. Low back pain is the most common musculoskeletal disorder. Hydrotherapy may assist a variety of pathological conditions, including low back pain. The purpose of the study is to examine the effectiveness of hydrotherapy in chronic low back pain.

Methods. A comprehensive search of PubMed, MEDLINE, Elsevier, and Google Scholar was conducted for randomized controlled trials published in the period of 2009-2019 that investigated therapeutic aquatic exercise for low back pain. Particularly, the examined variables were (a) pain, (b) disability, (c) quality of life, (d) functional ability and physical condition, (e) psychological state, (f) body composition, (h) vertebral height and nerve compression symptoms, and (i) kinesiophobia. PEDro scale, which measures the methodological quality of randomized studies, was used.

Results. Overall, 13 studies were included and the results showed a relief of pain and disability and an improvement of quality of life and psychological state after hydrotherapy. In accordance with the PEDro scale, the average methodological quality of the studies was 5.08/10.

Conclusions. Hydrotherapy may have a positive effect in patients with chronic low back pain. Further high-quality studies on a larger scale are required to confirm these results.

Key words: hydrotherapy, back pain, disability, quality of life, psychological state
\end{abstract}

\section{Introduction}

Over the course of life, $80 \%$ of people experience low back pain (LBP) [1] and $26 \%$ of American adults report pain on at least 1 day every 3 months [2]. It is estimated that $70-85 \%$ of the working population have had an episode of LBP that restricted their physical activity and affected work performance and quality of life [3-5], with many reports of long periods of absence from work [6, 7]. Also, health professionals like physicians and nurses are burdened with LBP because they do not apply principles of ergonomics [8]. In addition, people with LBP present discoordination in the function of different body parts, in sit-to-stand and stand-to-sit movement patterns [9]. Women aged 60-64 years with lower education and financial situation below the average have more functional restrictions due to their LBP [10]. In most men leading sedentary lifestyle with excess body weight and low physical activity, a strong relation is observed of these factors with the occurrence of spinal back pain [11].

Hydrotherapy is a method of rehabilitation with a particular research interest regarding its usefulness in the treatment of chronic LBP. The unique properties of water reduce joint stress, as well as the axial loading of the spine [12]. Also, the continuous movements of limbs against water resistance lead to muscle strengthening [13] and cardiovascular benefits [14], especially in subjects with low levels of physical fitness [15]. The buoyancy allows for a greater range of motion by supporting body weight and, at the same time, changing the depth helps to develop resistance [16]. The aquatic environment allows the participant to perform movements that are usually difficult or impossible on land and it has been shown that the desired exercise intensity can be achieved by regulating the speed of motion in water [17].

Pain intensity, disability, and quality of life were variables examined in LBP patients with the use of different scales, such as visual analogue scale, the Oswestry Disability Questionnaire, the Roland Morris Disability Questionnaire, or Short Form-36/12 [18-22]. Also, the functional and psychological state of LBP patients were investigated with a number of assessment tools [18, 23-25].

The aim of the present systematic review was to examine the effect of hydrotherapy on (a) pain, (b) disability, (c) quality of life, (d) functional ability and physical condition, (e) psychological state, (f) body composition, (h) vertebral height and nerve compression symptoms, and (i) kinesiophobia in participants with LBP. The study has an important clinical relevance since hydrotherapy may reduce LBP and the disability and enhance the patients' psychological state and quality of life. As a result, health professionals may use hydrotherapy to help their patients holistically. Also, hydrotherapy may promote rehabilitation through reducing muscle spasm and pain and improving functional ability and quality of life.

In their systematic reviews, Waller et al. [26], Olson et al. [27], and Shi et al. [28] examined the efficacy of therapeutic aquatic exercise in the treatment of LBP. Waller et al. [26] identified 7 relevant studies, published between 1990 and 2007 , assessing pain, disability, and the number of days of sick leave. Olson et al. [27] included only 3 randomized controlled trials, published in 2004, 2004, and 2009, evaluating pain, disability, and quality of life by using the PEDro scale as a methodological assessment tool. Shi et al. [28] analysed 8 relevant randomized controlled trials, published between

Correspondence address: Anna Christakou, Department of Physiotherapy, University of West Attica, 28 Agiou Spyridonos, 12243 , Athens, Greece, e-mail: achristakou@phed.uoa.gr 
1997 and 2014, examining pain and quality of life in participants with LBP. Waller et al. [26] and Shi et al. [28] did not use the PEDro scale for the methodological quality assessment of the randomized controlled trials.

The advantages of the present study in comparison with the 3 aforementioned systematic reviews are: (a) the inclusion of more recently published studies [18, 19, 29, 30]; (b) the use of the PEDro scale, which is a valid and reliable scale for assessing the methodological quality of randomized controlled trials worldwide; and (c) the assessment of more examined variables, such as psychological state, body composition, vertebral height, nerve compression symptoms, and kinesiophobia. The present study is a part of a bachelor degree thesis of the Department of Physiotherapy.

\section{Subjects and methods}

\section{Search strategy}

The Preferred Reporting Items for Systematic Reviews and Meta-Analyses (PRISMA) directions were followed and randomized controlled trials published in the period of 20092019 were chosen from 4 different databases: PubMed, MEDLINE, Elsevier, and Google Scholar. The following key words and their combinations were applied: 'hydrotherapy,' 'low back pain,' 'disability,' 'aquatic exercise,' 'quality of life,' 'functional ability,' 'physical condition,' 'psychological state,' 'body composition,' 'nerve compression symptoms,' and 'kinesiophobia'. Furthermore, the lists of references of the se-

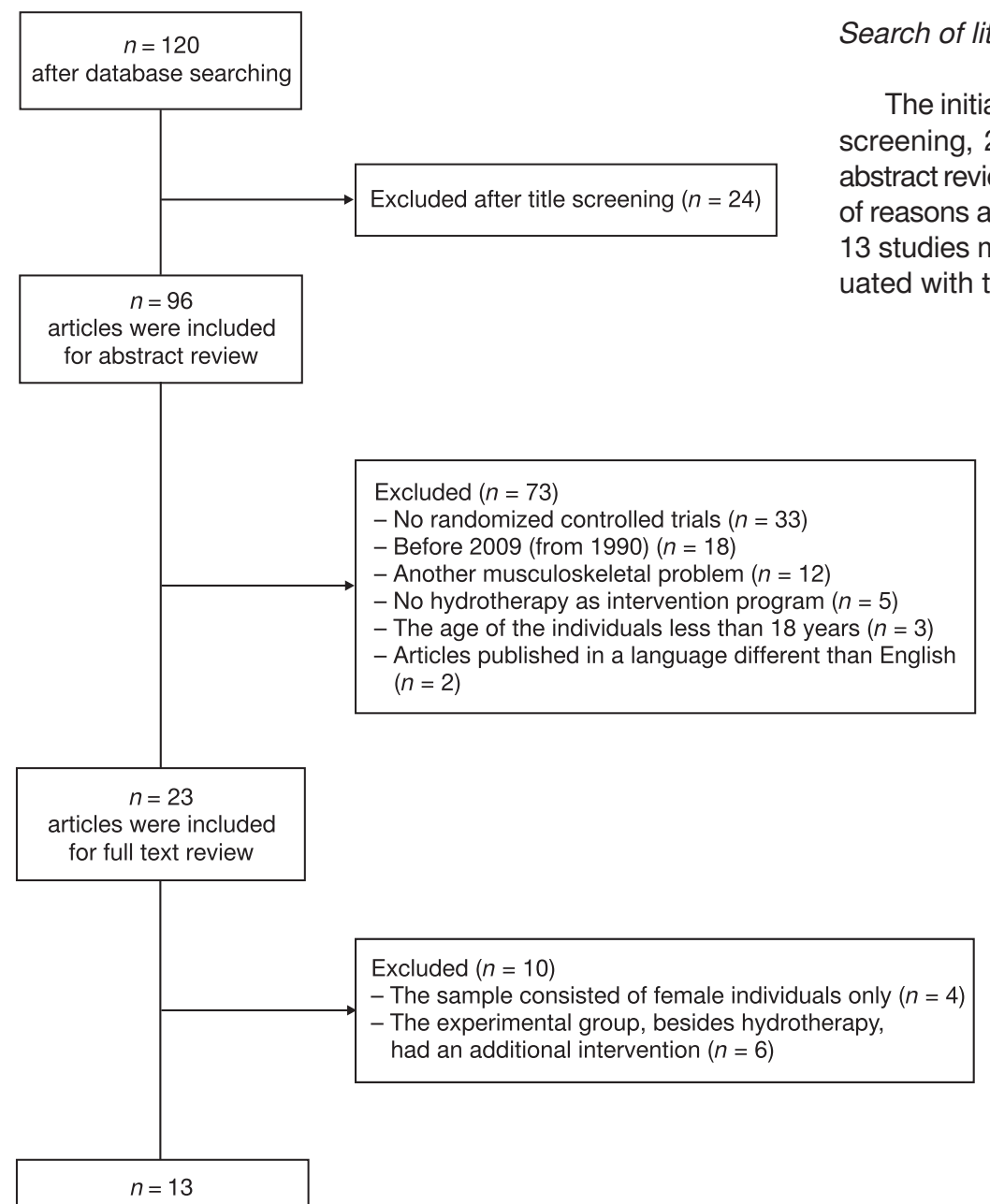

articles met the inclusion criteria lected articles were also examined for supplementary article investigation.

\section{Study selection}

\section{Inclusion criteria}

Studies were considered for inclusion if they met the following criteria: (a) adult population, (b) chronic LBP, (c) hydrotherapy as an intervention, (d) date of publication: 20092019, (e) existence of the full text of the published study in English and in electronic form, and (f) only randomized controlled trials.

\section{Exclusion criteria}

Studies were considered for exclusion if they met the following criteria: (a) other medical condition than chronic LBP; (b) intervention other than hydrotherapy (e.g., alternative treatments, balneotherapy, spa therapy, spa stay); (c) date of publication before 2009; and (d) existence of the full text of the published study in a language other than English.

\section{Examined variables}

The variables examined in the study were the following: (a) pain, (b) disability, (c) quality of life, (d) functional ability and physical condition, (e) psychological state, (f) body composition, (h) vertebral height and nerve compression symptoms, and (i) kinesiophobia.

\section{Search of literature}

The initial literature search showed 120 articles. After title screening, 24 were excluded and 96 papers remained for stract review. A total of 73 articles were excluded for a variety ns and 23 were included for full text review (Figure 1) 13 studies met all the inclusion criteria and were finally evaluated with the PEDro scale. 


\section{Quality assessment}

The PEDro scale was used to assess the methodological quality of the included studies [31]. It is a 10-point scale which addresses external and internal validity and has been found to be valid and reliable. Studies are evaluated as low quality if they score $0-3$, moderate quality if they score $4-6$, and high quality if the score is $7-10[32,33]$.

\section{Ethical approval}

The conducted research is not related to either human or animal use.

\section{Results}

\section{Sample}

The study sample consisted of adults suffering from LBP (including elderly, pregnant participants, various professional groups).

\section{Methodological quality of trials}

In accordance with the selection and rejection criteria, 13 studies were finally accepted for the present study (Figure 1). The PEDro scale was used to assess the quality of the trial methodology. The average methodological quality of the studies was 5.08/10. In particular, there were 11 studies of moderate methodological quality [18-20, 22, 24, 25, 29, $34-37]$ and 2 studies of high methodological quality [21, 30] (Table 1).

\section{Intervention}

The type of hydrotherapy program was therapeutic exercise in water, which included warm-up exercises, aerobic exercises, and rehabilitation exercises. The duration of the program differed from study to study and ranged from 2 weeks to 12 months. The exercise was applied 2-3 times a week, for 15-60 min per session. The intensity of the exercise was not reported in the analysed studies (Table 2). The aquatic therapy program usually involved warm-up, 15-20 min of resistance exercise for lower body muscles, 20-25 min of aerobic exercise incorporating large muscle mass, and $10 \mathrm{~min}$ of cool-down lower body static stretching exercises [24, 25, 30]. Constantino and Romiti [22] and Han et al. [36] applied a hydrotherapy program which included walking exercises, bilateral stretching, and selective muscle strengthening exercises. The aerobic regimen by Irandoust and Taheri [29] consisted of exercises such as water walking, jogging, walking and jogging in lifts, supported squats, outer/inner thigh scissors, and forward and backward leg glide. Each movement during resistance training was conducted with specialized equipment to increase water resistance. Bello et al. [34] reported that their aquatic program involved warm up, stretching and strengthening of the major lower back muscles and abdominal muscles, spinal stabilization, as well as lateral rotation techniques for the trunk and a cool-down phase. The sessions were held twice weekly (45-60 min each) for 6 weeks. Two repetitions of each static stretching were performed per muscle group, with each lasting $20 \mathrm{~s}$.

\section{Discussion}

The effectiveness of various forms of hydrotherapy in the management of chronic LBP has been established in recent years through a number of randomized controlled trials. Overall, 13 studies were examined in the present systematic review with the PEDro scale and revealed that hydrotherapy had a moderate positive effect on LBP. Similarly, Shi et al. [28] in their meta-analysis reported a relief of pain and an improvement in physical function after aquatic exercise, but no significant effectiveness with regard to general mental health in the aquatic group. On the other hand, Waller et al. [26] observed in their systematic review that therapeutic aquatic exercise had no better beneficial effects than other interventions, and the methodological quality of all included studies was considered low. In addition, Olson et al. [27] concluded in their review that aquatic exercise did not always prove more effective when compared with other forms of conservative treatment.

Table 1. PEDro scale scoring of the analysed studies

\begin{tabular}{|c|c|c|c|c|c|c|c|c|c|c|c|c|}
\hline \multirow{2}{*}{ No. } & \multirow{2}{*}{ Studies } & \multicolumn{10}{|c|}{ Criteria of the PEDro scale } & \multirow{2}{*}{ Total score } \\
\hline & & 1 & 2 & 3 & 4 & 5 & 6 & 7 & 8 & 9 & 10 & \\
\hline 1 & Abadi et al. [18] & 1 & 0 & 1 & 0 & 0 & 0 & 1 & 0 & 1 & 1 & $5 / 10$ \\
\hline 2 & Baena-Beato et al. [24] & 0 & 0 & 1 & 0 & 0 & 1 & 0 & 0 & 1 & 1 & $4 / 10$ \\
\hline 3 & Baena-Beato et al. [25] & 0 & 0 & 1 & 0 & 0 & 1 & 0 & 0 & 1 & 1 & $4 / 10$ \\
\hline 4 & Bello et al. [34] & 0 & 0 & 1 & 0 & 1 & 0 & 0 & 0 & 1 & 1 & $4 / 10$ \\
\hline 5 & Constantino and Romiti [22] & 1 & 0 & 1 & 0 & 0 & 0 & 1 & 1 & 1 & 1 & $6 / 10$ \\
\hline 6 & Cuesta-Vargas et al. [20] & 1 & 0 & 1 & 0 & 1 & 0 & 1 & 0 & 1 & 1 & $6 / 10$ \\
\hline 7 & Cuesta-Vargas et al. [21] & 1 & 1 & 1 & 0 & 0 & 0 & 1 & 1 & 1 & 1 & $7 / 10$ \\
\hline 8 & Dundar et al. [35] & 0 & 0 & 1 & 0 & 0 & 1 & 1 & 0 & 1 & 1 & $5 / 10$ \\
\hline 9 & Han et al. [36] & 1 & 0 & 1 & 0 & 0 & 0 & 1 & 0 & 0 & 1 & $4 / 10$ \\
\hline 10 & Irandoust and Taheri [29] & 1 & 0 & 1 & 0 & 0 & 0 & 0 & 0 & 1 & 1 & $4 / 10$ \\
\hline 11 & Keane [19] & 1 & 1 & 1 & 0 & 0 & 0 & 0 & 0 & 1 & 1 & $5 / 10$ \\
\hline 12 & Pires et al. [30] & 1 & 1 & 1 & 0 & 0 & 1 & 1 & 1 & 1 & 1 & $8 / 10$ \\
\hline 13 & Simmerman et al. [37] & 0 & 0 & 1 & 0 & 0 & 0 & 1 & 0 & 1 & 1 & $4 / 10$ \\
\hline
\end{tabular}


Table 2. Brief description of the 13 included studies

\begin{tabular}{|c|c|c|c|c|c|c|c|}
\hline No. & Studies & $\begin{array}{c}\text { Sample } \\
\text { (number } \\
\text { of withdrawn } \\
\text { participants) }\end{array}$ & Intervention & $\begin{array}{l}\text { Duration, } \\
\text { frequency, } \\
\text { intensity } \\
\text { of intervention }\end{array}$ & $\begin{array}{l}\text { Dependent } \\
\text { variables }\end{array}$ & $\begin{array}{l}\text { Evaluation/ } \\
\text { re-assessment }\end{array}$ & Results \\
\hline 1 & $\begin{array}{c}\text { Abadi } \\
\text { et al. [18] }\end{array}$ & $\begin{array}{c}39 \\
\text { A: } 19 \\
\text { B: } 20\end{array}$ & $\begin{array}{c}\text { A: Aquatic } \\
\text { exercise } \\
\text { B: Usual care }\end{array}$ & $\begin{array}{l}2 \text { times/week, } \\
60 \mathrm{~min} / \text { session, } \\
12 \text { weeks }\end{array}$ & Disability & $\begin{array}{l}\text { Before } \\
\text { the intervention } \\
\text { program and after } \\
\text { the intervention } \\
\text { program period } \\
\text { of } 12 \text { weeks }\end{array}$ & $\begin{array}{c}\text { Improvement in LBP disability sections, } \\
\text { including pain intensity, personal care, } \\
\text { and the ability of sitting, standing, sleeping, } \\
\text { and employment/home-making. } \\
\text { No significant difference in lifting, walking, } \\
\text { social life, or traveling abilities }\end{array}$ \\
\hline 2 & $\begin{array}{l}\text { Baena-Beato } \\
\text { et al. [24] }\end{array}$ & $\begin{array}{c}78(4) \\
\text { A: } 24(3) \\
\text { B: } 24(6) \\
\text { C: } 26(11)\end{array}$ & $\begin{array}{l}\text { A: Exercise } \\
\text { in a pool - } \\
2 \text { days/week } \\
\text { B: Exercise } \\
\text { in a pool - } \\
3 \text { days/week } \\
\text { C: Usual care }\end{array}$ & $\begin{array}{l}\text { A: } 55-60 \mathrm{~min}, \\
2 \text { times/week, } \\
8 \text { weeks } \\
\text { B: } 55-60 \mathrm{~min} \text {, } \\
3 \text { times/week, } \\
8 \text { weeks }\end{array}$ & $\begin{array}{l}\text { Pain, disability, } \\
\text { quality of life, } \\
\text { body composition, } \\
\text { physical condition }\end{array}$ & $\begin{array}{l}\text { Before and after } \\
\text { the therapeutic } \\
\text { intervention } \\
\left(8^{\text {th }} \text { week }\right)\end{array}$ & $\begin{array}{c}\text { Pain and disability reduction, improvement } \\
\text { in quality of life and fitness related } \\
\text { to health. No significant differences } \\
\text { in body composition }\end{array}$ \\
\hline 3 & $\begin{array}{l}\text { Baena-Beato } \\
\text { et al. [25] }\end{array}$ & $\begin{array}{c}49(38) \\
\text { A: } 24(3) \\
B: 25(8)\end{array}$ & $\begin{array}{l}\text { A: Aquatic } \\
\text { exercise } \\
\text { B: Usual care }\end{array}$ & $\begin{array}{l}40 \text { sessions, } \\
5 \text { days/week, } \\
2 \text { months }\end{array}$ & $\begin{array}{l}\text { Pain, disability } \\
\text { quality of life, } \\
\text { body composition, } \\
\text { health-related } \\
\text { fitness }\end{array}$ & $\begin{array}{l}\text { Before and after } \\
\text { the therapeutic } \\
\text { intervention } \\
\text { (pre- and post- } \\
\text { intervention } \\
\text { assessments) }\end{array}$ & $\begin{array}{c}\text { Significant improvements in body } \\
\text { composition and fitness, pain, disability, } \\
\text { and the standardized physical component } \\
\text { of quality-of-life domains. No significant } \\
\text { changes in the mental component. In the } \\
\text { control group, no significant change in any } \\
\text { variable }\end{array}$ \\
\hline 4 & $\begin{array}{l}\text { Bello et al. } \\
\quad[34]\end{array}$ & $\begin{array}{l}16(4) \\
A: 8(2) \\
B: 8(2)\end{array}$ & $\begin{array}{l}\text { A: Exercise } \\
\text { in a pool } \\
\text { B: Land-based } \\
\text { exercises }\end{array}$ & $\begin{array}{c}2 \text { times/week } \\
\text { (45-60 min each), } \\
6 \text { weeks }\end{array}$ & $\begin{array}{c}\text { Pain, spinal } \\
\text { flexibility } \\
\text { (flexion, extension) }\end{array}$ & $\begin{array}{l}\text { Before and after } \\
\text { the therapeutic } \\
\text { intervention } \\
\left.\text { (6 } 6^{\text {th }} \text { week }\right)\end{array}$ & $\begin{array}{l}\text { Improvement in the variables of pain, } \\
\text { spinal flexibility (flexion, extension) }\end{array}$ \\
\hline 5 & $\begin{array}{l}\text { Constantino } \\
\text { and Romiti } \\
\text { [22] }\end{array}$ & $\begin{array}{c}64(10) \\
A: 27(5) \\
B: 27(5)\end{array}$ & $\begin{array}{l}\text { A: Back School } \\
\text { program } \\
\text { B: Hydrotherapy } \\
\text { program }\end{array}$ & $\begin{array}{l}60 \text { min, } \\
2 \text { times/week, } \\
12 \text { weeks }\end{array}$ & $\begin{array}{l}\text { Disability, } \\
\text { quality of life }\end{array}$ & $\begin{array}{l}\text { Before and after } \\
\text { treatment } \\
(12 \text { weeks }) \\
\text { and } 3 \text { months } \\
\text { after treatment }\end{array}$ & $\begin{array}{l}\text { No significant differences between } \\
\text { the } 2 \text { programs }\end{array}$ \\
\hline 6 & $\begin{array}{l}\text { Cuesta-Vargas } \\
\text { et al. [20] }\end{array}$ & $\begin{array}{c}49(3) \\
\text { A: } 25(2) \\
B: 24(1)\end{array}$ & $\begin{array}{c}\text { A: MMP } \\
B: M M P+D W R\end{array}$ & $\begin{array}{l}60 \text { min MMP + } \\
20 \text { min DWR, } \\
3 \text { times/week, } \\
15 \text { weeks }\end{array}$ & $\begin{array}{l}\text { Pain, disability, } \\
\text { health status, } \\
\text { muscle strength } \\
\text { and endurance, } \\
\text { lumbar range } \\
\text { of motion }\end{array}$ & $\begin{array}{l}\text { Before and after } \\
\text { each intervention }\end{array}$ & $\begin{array}{l}\text { Similar significant improvements in both } \\
\text { intervention groups. No significant } \\
\text { differences between groups }\end{array}$ \\
\hline 7 & $\begin{array}{l}\text { Cuesta-Vargas } \\
\text { et al. [21] }\end{array}$ & $\begin{array}{c}58 \\
\text { A: } 29 \\
\text { B: } 29\end{array}$ & $\begin{array}{l}\text { A: DWR + } \\
\text { standard GP } \\
\text { B: GP }\end{array}$ & $\begin{array}{l}+30 \text { min DWR, } \\
3 \text { times/week, } \\
15 \text { weeks }\end{array}$ & $\begin{array}{l}\text { Pain, disability, } \\
\text { mental health, } \\
\text { physical health }\end{array}$ & $\begin{array}{l}\text { Before and after } \\
\text { the therapeutic } \\
\text { intervention, } \\
\text { at } 4-6-12 \text { months } \\
\text { of follow-up }\end{array}$ & $\begin{array}{l}\text { Improvement in the variables of pain, } \\
\text { physical and mental health, disability } \\
\text { in the DWR group }\end{array}$ \\
\hline 8 & $\begin{array}{c}\text { Dundar et al. } \\
\text { [35] }\end{array}$ & $\begin{array}{l}69(4) \\
\text { A: } 32 \\
B: 33\end{array}$ & $\begin{array}{l}\text { A: Aquatic } \\
\text { exercise } \\
\text { B: Land-based } \\
\text { exercise } \\
\text { (home-based } \\
\text { exercise) }\end{array}$ & $\begin{array}{c}\text { A: } 60 \text { min, } \\
5 \text { times/week, } \\
4 \text { weeks } \\
\text { B: } 60 \text {-min program, } \\
4 \text { weeks, each exer- } \\
\text { cise once/day with } \\
\text { 15-20 repetitions } \\
\text { alone }\end{array}$ & $\begin{array}{l}\text { Disability, spinal } \\
\text { mobility, pain, } \\
\text { quality of life }\end{array}$ & $\begin{array}{l}\text { Before treatment } \\
\text { (week 0) and } \\
\text { after treatment } \\
\text { (week } 4 \text { and } \\
\text { week 12) }\end{array}$ & $\begin{array}{c}\text { Better statistically significant } \\
\text { improvements in disability and physical } \\
\text { function in the aquatic exercise group than in } \\
\text { the control group }\end{array}$ \\
\hline 9 & Han et al. [36] & $\begin{array}{c}27(8) \\
\text { A: } 9 \\
\text { B: } 10\end{array}$ & $\begin{array}{c}\text { A: Aquatic } \\
\text { exercise group } \\
\text { B: Control group }\end{array}$ & $\begin{array}{c}50 \text { min, } \\
5 \text { times/week, } \\
10 \text { weeks }\end{array}$ & $\begin{array}{l}\text { Pain, muscle } \\
\text { strength }\end{array}$ & $\begin{array}{l}\text { Before and after } \\
\text { the therapeutic } \\
\text { intervention } \\
\left(10^{\text {th }} \text { week }\right)\end{array}$ & $\begin{array}{l}\text { Significantly reduced pain, } \\
\text { improvement in muscle strength } \\
\text { in the aquatic group }\end{array}$ \\
\hline 10 & $\begin{array}{c}\text { Irandoust } \\
\text { and Taheri } \\
{[29]}\end{array}$ & $\begin{array}{c}32 \\
\text { A: } 16 \\
\text { B: } 16\end{array}$ & $\begin{array}{c}\text { A: Aquatic } \\
\text { training group } \\
\text { B: Control group }\end{array}$ & $\begin{array}{l}60 \text { min, } \\
3 \text { times/week, } \\
12 \text { weeks }\end{array}$ & $\begin{array}{l}\text { BMI, PBF, WHR, } \\
\text { pain, muscle mass } \\
\text { of the trunk }\end{array}$ & $\begin{array}{c}\text { Before and after } \\
\text { the therapeutic } \\
\text { intervention } \\
\left(12^{\text {th }} \text { week }\right)\end{array}$ & $\begin{array}{l}\text { Significant improvement in all variables } \\
\text { and muscle mass of the trunk } \\
\text { in the aquatic group }\end{array}$ \\
\hline 11 & Keane [19] & $\begin{array}{l}42(13) \\
\text { A: } 10 \\
\text { B: } 10 \\
\text { C: } 9\end{array}$ & $\begin{array}{l}\text { A: AquaStretch } \\
\text { B: Land-based } \\
\text { stretching } \\
\text { (supervised) } \\
\text { C: Control group }\end{array}$ & $\begin{array}{c}30 \text { min, } \\
2 \text { times/week, } \\
12 \text { weeks }\end{array}$ & $\begin{array}{c}\text { Pain, } \\
\text { kinesiophobia }\end{array}$ & $\begin{array}{l}\text { Before and after } \\
\text { the therapeutic } \\
\text { intervention } \\
\left(12^{\text {th }} \text { week }\right)\end{array}$ & $\begin{array}{c}\text { Significantly better reduction in pain } \\
\text { in the AquaStretch group. A combination } \\
\text { of AquaStretch and land-based stretching } \\
\text { would provide a more cost-effective } \\
\text { treatment programme }\end{array}$ \\
\hline 12 & Pires et al. [30] & $\begin{array}{c}86(34) \\
A: 30 \\
B: 32\end{array}$ & $\begin{array}{c}\text { A: Aquatic } \\
\text { exercise and pain } \\
\text { neurophysiology } \\
\text { education } \\
\text { B: Aquatic } \\
\text { exercise alone }\end{array}$ & $\begin{array}{c}\text { A: } 12 \text { sessions, } \\
6 \text { weeks } \\
\text { of } 2 \text { sessions } \\
\text { of pain neurophysio- } \\
\text { logy education } \\
\text { B: } 12 \text { sessions/ } \\
6 \text { weeks }\end{array}$ & $\begin{array}{l}\text { Pain, disability, } \\
\text { kinesiophobia }\end{array}$ & $\begin{array}{l}\text { Before and after } \\
\text { the therapeutic } \\
\text { intervention } \\
\left(6^{\text {th }} \text { week) and }\right. \\
\text { at } 3 \text { months } \\
\text { of follow-up }\end{array}$ & $\begin{array}{l}\text { Significant decrease in pain intensity } \\
\text { in the education group at } 3 \text { months } \\
\text { of follow-up. No significant differences } \\
\text { in functional disability or kinesiophobia } \\
\text { between the } 2 \text { groups at any time }\end{array}$ \\
\hline 13 & $\begin{array}{l}\text { Simmerman } \\
\text { et al. [37] }\end{array}$ & $\begin{array}{c}98(38) \\
A: 30 \\
B: 30\end{array}$ & $\begin{array}{l}\text { A: Land-based } \\
\text { supine flexion } \\
\text { B: Aquatic } \\
\text { vertical traction }\end{array}$ & $\begin{array}{l}\text { A: } 15 \text { min of } \\
\text { land-based supine } \\
\text { flexion position } \\
\text { B: } 15 \text { min of aquatic } \\
\text { vertical traction }\end{array}$ & $\begin{array}{l}\text { Spinal height } \\
\text { of vertebrae, pain, } \\
\text { nerve root } \\
\text { compression }\end{array}$ & $\begin{array}{l}\text { Before and after } \\
\text { each therapeutic } \\
\text { intervention }\end{array}$ & $\begin{array}{l}\text { Decreases in pain significantly greater } \\
\text { and centralization of symptoms after } \\
\text { aquatic vertical suspension. A significant } \\
\text { correlation between height change and pain } \\
\text { reduction for the aquatic intervention only }\end{array}$ \\
\hline
\end{tabular}




\section{Pain and disability}

Irandoust and Taheri [29] investigated the effect of hydrotherapy in the elderly who suffered from non-specific LBP. They found that the participants' body mass index, percentage of body fat, waist-hip ratio, trunk muscle mass, and LBP improved significantly after the intervention. Similarly, BaenaBeato et al. [25] examined the prognostic factors and disability change after hydrotherapy. Reduced levels of pain and disability were observed, and quality of life, body mass index, and physical fitness were improved. Moreover, Pires et al. [30] studied hydrotherapy in patients with chronic LBP, comparing the effects of a combination of exercise in water and training on neurophysiology of pain with those of exercise in water only. They found that providing neurophysiology pain management was a clinically effective supplement to hydrotherapy.

The intensity of general pain and disability were the 2 variables examined by approximately all the studies with the use of visual analogue scale [19-21, 24, 30, 34], Quebec Back Pain Disability Scale (QBPDS) [30], Oswestry Disability Questionnaire [18, 19, 25, 35], Roland Morris Disability Questionnaire [20-22], and Short Form-12/36 [20-22, 25, 26, 35], which assesses the quality of life and general health of the tested subjects. According to the high methodological quality study by Pires et al. [30], general body pain was reduced by applying exercise in water. The majority of studies with moderate $[24,25,34]$ methodological quality indicate that general pain and disability were reduced in the experimental group. In another study of moderate research quality [37], pain relief was an inconsistent finding. Several of the studies with moderate $[19,20,24,25,34]$ and high $[21,30]$ methodological quality indicate that disability decreased in the experimental group. However, it is considered necessary to evaluate pain and disability among LBP patients in additional randomized controlled studies of high methodological quality to draw more definite conclusions.

\section{Functional/physical condition and psychological state}

Functionality and physical condition of LBP patients were evaluated through the physiological variables of muscle strength and strength of upper limbs and torso, neck discomfort, and flexibility. These variables were tested in a variety of tests, such as the handgrip muscle strength test, the curl-up, the sit-and-reach flexibility test, the Rockport 1-mile gait test [24, 25], the modified Schober flexion technique, and modified Schober extension technique [34]. Han et al. [36] examined the strength of the participants with an isokinetic dynamometer. Functional ability and physical condition were found to be improved in the above 4 studies of intermediate methodological quality, respectively. In a study of moderate methodological quality [24], an improvement in the quality of life and fitness in the control group was found. Hydrotherapy helped to improve physical fitness and body mass index, as found by Baena-Beato et al. [24, 25] in 2 studies of moderate methodological quality. Constantino and Romiti [22] in a study of moderate methodological quality observed that exercise in water improved the overall health of the tested back pain patients compared with the control group.

Research on the psychological status of LBP patients is considered necessary to evaluate their quality of life. Variables such as depression and anxiety are required to be controlled by specialized validated measuring instruments, such as the Beck Depression Inventory and anxiety ques- tionnaires, although sub-scales of questionnaires such as SF-36 or SF-12 have been widely used $[20,21]$.

\section{Body composition and kinesiophobia}

Body composition was improved in 2 studies [25, 29] of moderate methodological quality. According to the results of 2 studies of moderate and high methodological quality, the kinesiophobia of the experimental group improved compared with that in the control group [19, 30]. In particular, Keane [19] suggests hydrotherapy and stretching as a beneficial complementary technique, alongside exercise on land, in patients with chronic LBP and kinesiophobia.

\section{Vertebral height and nerve compression symptoms}

Vertebral height and nerve compression symptoms were improved in research by Simmerman et al. [37], of moderate methodological quality. In particular, significantly higher temporary improvements were found in the intensity of pain, concentration of nervous compression symptoms, and height of the vertebrae following the intervention of aqueous vertical suspension. No other study has presented similar results regarding this variable.

\section{Limitations}

This systematic review has some limitations. Firstly, the very nature of a systematic review inhibits a broad and diverse approach to the literature. For example, this systematic review is limited to randomized controlled trials published, approximately, within the recent 10 years. It is possible that the literature published prior to this period may be relevant to the review question. Similarly, while all attempts were made to interrogate and access all relevant literature, it is possible that some publications may have been missed in the search process. This could have been due to the fact of searching chosen databases and using specific key words and terminologies. However, as this review identified enough randomized controlled trials on the same topic, the body of evidence to inform the review question is considerable. Secondly, the inclusion of English-language articles published in scientific journals is regarded as a limitation, too, as it was possible not to find other related studies or investigations which observed negative results and therefore were not published. Thirdly, changes in the examined variables were not recorded or evaluated at the clinical level, but only in terms of their statistical significance. Statistical significance may not always reflect the clinical significance of the results [38], so further research is needed. Finally, the absence of reference to the exact age of the participants in each and every study is also considered as a limitation.

\section{Directions for future research and clinical practice}

Hydrotherapy for LBP is a research topic which has been extensively evaluated in literature in recent years. Nevertheless, there are still some aspects requiring further evaluation, as they are of interest from both the clinical and economic perspective.

It is proposed to create new prospective controlled experimental designs with enough variables rated for both clinical and statistical significance. The new studies using valid logging protocols, based on a specific theoretical background will contribute to valid, credible, and objective results. Simultaneous evaluation of psychological and physiological 
factors for the improvement of back pain would help to create a model for the recovery of the syndrome. Therefore, it is necessary to evaluate the exercise programs for a wider range of physiological and psychological parameters of the recovery process, with valid and reliable tools, by using appropriate statistical analysis in order to examine differences between research teams in small sample studies for greater reliability of research results.

Future investigations are required to follow a blind measurement process for participants, therapists, and evaluators, applying a large number of participants assigned to experimental and control groups with valid methodological procedures. Further research is needed to study the effect of hydrotherapy in a sample of obese or overweight LBP patients in order to establish if individualized and specialized exercise programs in water will be beneficial for these people. Other investigations should validly record patient compliance in rehabilitation programs. Session assessment or the time the patient was attending the exercise program divided by the number of treatment sessions that were scheduled to be performed may be a more appropriate measure. Such a recording would be important because it allows to calculate the 'dose' of the therapeutic intervention that the patient followed.

\section{Conclusions}

According to the present study, hydrotherapy is suggested for patients suffering from chronic LBP. Balance and coordination are enhanced by exercise in water and hydrotherapy can be used at an early stage of the rehabilitation program to introduce patients to later exercises on land. Therapeutic exercise in water can be a safe and effective method for patients with chronic LBP. The combination of 2 types of exercise (in water and on land) in the same treatment program is encouraged and more beneficial.

In summary, this systematic review has shown that although therapeutic interventions and study variables are considered heterogeneous, hydrotherapy appears to have a moderate positive effect with reference to LBP syndrome. The methodological quality of the studies regarding the effectiveness of hydrotherapy in LBP was moderate as estimated by the PEDro scale. Taking into account the limitations of this systematic review, proposals are being made for further research that aims at designing new experimental protocols to confirm the effectiveness of hydrotherapy in LBP.

\section{Disclosure statement}

No author has any financial interest or received any financial benefit from this research.

\section{Conflict of interest}

The authors state no conflict of interest.

\section{References}

1. Urquhart DM, Hoving JL, Assendelft WWJJ, Roland M, van Tulder MW. Antidepressants for non-specific low back pain. Cochrane Database Syst Rev. 2008;2008(1): CD001703; doi: 10.1002/14651858.CD001703.pub3.

2. Deyo RA, Mirza SK, Martin BI. Back pain prevalence and visit rates: estimates from U.S. national surveys, 2002. Spine. 2006;31(23):2724-2727; doi: 10.1097/01.brs. 0000244618.06877.cd.

3. Andersson GB. Epidemiological features of chronic lowback pain. Lancet. 1999;354(9178):581-585; doi: 10.1016/ S0140-6736(99)01312-4.
4. Deyo RA, Weinstein JN. Low back pain. N Engl J Med. 2001;344(5):363-370; doi: 10.1056/NEJM2001020134 40508.

5. Liddle SD, Baxter GD, Gracey JH. Exercise and chronic low back pain: what works? Pain. 2004;107(1-2):176190; doi: 10.1016/j.pain.2003.10.017.

6. Fritz JM, Irrgang JJ. A comparison of a modified Oswestry Low Back Pain Disability Questionnaire and the Quebec Back Pain Disability Scale. Phys Ther. 2001;81(2):776788; doi: 10.1093/ptj/81.2.776.

7. Breivik H, Collett B, Ventafridda V, Cohen R, Gallacher D. Survey of chronic pain in Europe: prevalence, impact on daily life, and treatment. Eur J Pain. 2006;10(4):287333; doi: 10.1016/j.ejpain.2005.06.009.

8. Dąbek J, Piotrkowicz J, Korzeń D, Gąsior Z. Knowledge and use of ergonomic principles in physicians and nurses with low back pain. Health Prob Civil. 2019;13(3):217224; doi: 10.5114/hpc.2019.81342.

9. Shafizadeh M. Movement coordination during sit-to-stand in low back pain people. Hum Mov. 2016;17(2):107-111; doi: 10.1515/humo-2016-0012.

10. Pocztarska-Głos A, Sidor M, Gawlik K, Bergier B, Stępień E, Baj-Korpak J, et al. Back pain as a factor of disability in women over 50 from Biała Podlaska and the surrounding areas. Health Prob Civil. 2019;13(4):264272; doi: 10.5114/hpc.2019.89950.

11. Moczek K, Gawlik K, Rosołek B. The relationship between physical activity and the prevalence of disabilities caused by back pain in men over 60 years of age. Adv Rehab. 2018;4:29-35; doi: 10.5114/areh.2018.83392.

12. Camilotti BM, Rodacki ALF, Israel VL, Fowler NE. Stature recovery after sitting on land and in water. Man Ther. 2009;14(6):685-689; doi: 10.1016/j.math.2009.03.007.

13. Campbell JA, D'Aquisto LJ, D'Aquisto DM, Cline MG. Metabolic and cardiovascular response to shallow water exercise in young and older women. Med Sci Sports Exerc. 2003;35(4):675-681; doi: 10.1249/01.MSS.000 0058359.87713.99.

14. Pöyhönen T, Sipilä S, Keskinen KL, Hautala A, Savo_ lainen J, Mälkiä E. Effects of aquatic resistance training on neuromuscular performance in healthy women. Med Sci Sports Exerc. 2002;34(12):2103-2109; doi: 10.1249/ 01.MSS.0000039291.46836.86.

15. Tsourlou T, Benik A, Dipla K, Zafeiridis A, Kellis S. The effects of a twenty-four-week aquatic training program on muscular strength performance in healthy elderly women. J Strength Cond Res. 2006;20(4):811-818; doi: 10.1519/R-18455.1.

16. Skelton DA, Dinan SM. Exercise for falls management: rationale for an exercise programme aimed at reducing postural instability. Physiother Theor Pr. 1999;15(2):105120; doi: 10.1080/095939899307801.

17. Moseley L. Combined physiotherapy and education is efficacious for chronic low back pain. Aust J Physiother. 2002;48(4):297-302; doi: 10.1016/s0004-9514(14)60169-0.

18. Abadi FH, Sankaravel M, Zainuddin FF, Elumalai G, Razli Al. The effect of aquatic exercise program on lowback pain disability in obese women. J Exerc Rehabil. 2019;15(6):855-860; doi: 10.12965/jer.1938688.344.

19. Keane LG. Comparing AquaStretch with supervised land based stretching for chronic lower back pain. J Bodyw Mov Ther. 2017;21(2):297-305; doi: 10.1016/j.jbmt.2016. 07.004.

20. Cuesta-Vargas Al, García-Romero JC, Arroyo-Morales M, Diego-Acosta AM, Daly DJ. Exercise, manual therapy, and education with or without high-intensity deep-water 
running for nonspecific chronic low back pain: a pragmatic randomized controlled trial. Am J Phys Med Rehabil. 2011;90(7):526-534, quiz 535-538; doi: 10.1097/ PHM.0b013e31821a71d0.

21. Cuesta-Vargas Al, Adams N, Salazar JA, Belles A, Hazañas $S$, Arroyo-Morales M. Deep water running and general practice in primary care for non-specific low back pain versus general practice alone: randomized controlled trial. Clin Rheumatol. 2012;31(7):1073-1078; doi: 10.1007/s10067-012-1977-5.

22. Constantino C, Romiti D. Effectiveness of Back School program versus hydrotherapy in elderly patients with chronic non-specific low back pain: a randomized clinical trial. Acta Biomed. 2014;85(3):52-61.

23. Wiśniewski E, Zubrzycka A, Wroński Z, Hadamus A. Qualification for prevention of musculoskeletal diseases. Low back pain example. Adv Rehab. 2018;4:13-19; doi: 10.5114/areh.2018.83390.

24. Baena-Beato PÁ, Arroyo-Morales M, Delgado-Fernández M, Gatto-Cardia MC, Artero EG. Effects of different frequencies (2-3 days/week) of aquatic therapy program in adults with chronic low back pain. A non-randomized comparison trial. Pain Med. 2013;14(1):145158; doi: 10.1111/pme.12002.

25. Baena-Beato PÁ, Artero EG, Arroyo-Morales M, RoblesFuentes A, Gatto-Cardia MC, Delgado-Fernández M. Aquatic therapy improves pain, disability, quality of life, body composition and fitness in sedentary adults with chronic low back pain. A controlled clinical trial. Clin Rehabil. 2014;28(4):350-360; doi: 10.1177/0269215513504943.

26. Waller B, Lambeck J, Daly D. Therapeutic aquatic exercise in the treatment of low back pain: a systematic review. Clin Rehabil. 2009;23(1):3-14; doi: 10.1177/02692155 08097856.

27. Olson DA, Kolber MJ, Patel C, Pabian P, Hanney WJ. Aquatic exercise for treatment of low-back pain: a systematic review of randomized controlled trials. Am J Lifestyle Med. 2013;7(2):154-160; doi: 10.1177/155982761 2457323.

28. Shi Z, Zhou H, Lu L, Pan B, Wei Z, Yao X, et al. Aquatic exercises in the treatment of low back pain: a systematic review of the literature and meta-analysis of eight studies. Am J Phys Med Rehabil. 2018;97(2):116-122; doi: 10.1097/PHM.0000000000000801.

29. Irandoust $\mathrm{K}$, Taheri $\mathrm{M}$. The effects of aquatic exercise on body composition and nonspecific low back pain in elderly males. J Phys Ther Sci. 2015;27(2):433-435; doi: 10.1589/jpts.27.433.

30. Pires D, Brazete Cruz E, Caeiro C. Aquatic exercise and pain neurophysiology education versus aquatic exercise alone for patients with chronic low back pain: a randomized controlled trial. Clin Rehabil. 2015;29(6):538-547; doi: 10.1177/0269215514549033.

31. PEDro. PEDro scale. 1999. Available from: https://www. pedro.org.au/english/downloads/pedro-scale/.

32. Foley NC, Bhogal SK, Teasell RW, Bureau Y, Speechley MR. Estimates of quality and reliability with the physiotherapy evidence-based database scale to assess the methodology of randomized controlled trials of pharmacological and nonpharmacological interventions. Phys Ther. 2006;86(6):817-824; doi: 10.1093/ptj/86.6.817.

33. Maher CG, Sherrington C, Herbert RD, Moseley AM, Elkins M. Reliability of the PEDro scale for rating quality of randomized controlled trials. Phys Ther. 2003;83(8): 713-721; doi: 10.1093/ptj/83.8.713.
34. Bello Al, Kalu NH, Adegoke BOA, Ayepong-Badu S. Hydrotherapy versus land-based exercises in the management of chronic low back pain: a comparative study. J Musculoskelet Res. 2010;13(4):159-165; doi: 10.1142/S0218957710002594.

35. Dundar U, Solak O, Yigit I, Evcik D, Kavuncu V. Clinical effectiveness of aquatic exercise to treat chronic low back pain: a randomized controlled trial. Spine. 2009;34(14): 1436-1440; doi: 10.1097/BRS.0b013e3181a79618.

36. Han G, Cho M, Nam G, Moon T, Kim J, Kim S, et al. The effects on muscle strength and visual analog scale pain of aquatic therapy for individuals with low back pain. J Phys Ther Sci. 2011;23(1):57-60; doi: 10.1589/jpts.23.57.

37. Simmerman SM, Sizer PS, Dedrick GS, Apte GG, Brismée J-M. Immediate changes in spinal height and pain after aquatic vertical traction in patients with persistent low back symptoms: a crossover clinical trial. PM R. 2011;3(5):447-457; doi: 10.1016/j.pmrj.2011.01.010.

38. Christakou A, Zacharioudaki O. The effectiveness of water exercise on the fibromyalgia syndrome. Physiotherapy Issues / Themata Fisikotherapeias. 2010;6:101-108. 